\title{
Economical Wood Sawing with Circular Saw Blades of a New Design
}

\section{Ekonomično piljenje drva kružnom pilom novog dizajna}

\author{
Original scientific paper • Izvorni znanstveni rad \\ Received-prispjelo: 12. 7. 2011. \\ Accepted-prihvaćeno: 9. 2. 2012. \\ UDK: $630 * 822.33 ; 674.023$ \\ doi:10.5552/drind.2012.1121
}

\begin{abstract}
Material-saving and energy-saving belong to the basic requirements imposed on contemporary manufacturing processes. The realization of these processes gives measurable profits, not only economical but also ecological. In the case of wood sawing with circular saw blades, material-and energy-savings are dependent on total overall set of teeth (theoretical kerf) and teeth position accuracy in relation to the workpiece. Hence, it is necessary to achieve a decrease of both raw material and energy losses by the use of narrow-kerf saw blades, an increase of sawing accuracy, as well as a reduction of spacing in case of sawing with a gang of circular saws. However, meeting these requirements in the case of rip sawing with circular saw blades is a quite difficult issue and depends on many factors. The detailed analyses concerning ways of chip transportation in the kerf slot, saw blade stiffness, saw blade movement and workpiece feeding accuracy are the proof of these inconvenient technical problems in sawmills. Hence, the realization of economical wood sawing with circular saw blades seems not to be viable until the whole system of sawing fulfils the defined requirements. Thanks to the application of the proecological technology (circular saw blades of a new design), in the examined industrial case, the following results have been achieved: an increase of about $18 \%$ in the amount of side lumber, roughly $16 \%$ less sawdust (as an effect of kerf reduction) and about $16 \%$ lower values of the cutting power consumption.
\end{abstract}

Keywords: rip sawing, circular saw blade, increased yield of raw material

SAŽETAK・ Ušteda materijala i energije pripadaju temeljnim zahtjevima koji se nameću proizvodnim procesima. Realizacija ušteda donosi mjerljive profite, ali ne samo ekonomske, već i ekološke. Kad je riječ o piljenju drva kružnim pilama, uštede materijala i energije ovise o širini reznog brida (teorijskoj širini propiljka) $i$ točnosti položaja reznih bridova prema obratku. Dakle, nužno je osigurati smanjenje gubitaka materijala i energije uporabom tankih listova pila s malom širinom propiljka, povećati točnost piljenja te smanjiti razmak između listova pila pri piljenja slogom kružnih pila. Međutim, ispunjavanje tih zahtjeva pri piljenju kružnim pilama za uzdužno propiljivanje vrlo je teško i ovisi o brojnim činiteljima. Ozbiljne tehničke probleme s kojima se susreću pilanari potvrđuju i brojne provedene detaljne analize vezane za uklanjanje piljevine iz propiljka, napetost listova pila, gibanje lista pile i točnost posmaka obratka. Prema tomu, realizacija ekonomičnog piljenja kružnim pilama neće biti ostvariva dok cijeli sustav piljenja ne bude ispunjavao zadane zahtjeve. Zahvaljujući primjeni ekološki prihvatljive tehnologije (kružnih pila novog dizajna), u industrijskim su uvjetima postignuti ovi rezultati: oko $18 \%$

\footnotetext{
${ }^{1}$ Authors are professors at Faculty of Mechanical Engineering, Gdansk University of Technology, Gdansk, Poland. ${ }^{2}$ Author is the Director of GASSTECH Przedsiębiorstwo Produkcyjne Sp. z o. o. (PLC), Suwalki, Poland.

${ }^{1}$ Autori su profesori Strojarskog fakulteta Tehnološkog sveučilišta u Gdansku, Gdansk, Poljska. ${ }^{2}$ Autor je direktor tvrtke GASSTECH Przedsiębiorstwo Produkcyjne Sp. z o. o. (PLC), Suwalki, Poljska.
} 
povećanja količina krajnjih piljenica, oko $16 \%$ manje piljevine (što je rezultat smanjenja širine propiljka) i oko 16 \% manje potrošnje energije za piljenje.

Ključne riječi: uzdužno piljenje, list kružne pile, povećano iskorištenje sirovine

\section{INTRODUCTION}

\section{UVOD}

The ecological friendliness is a basic demand of contemporary manufacturing processes. In the field of wood sawing with circular saw blades, which is one of the basic cutting methods in the wood industry, the ecological friendliness is primarily connected with material- and energy-saving of the process. The application of the technologies in sawmills, which allow the users to reduce raw material losses and energy consumption, gives measurable advantages, not only economical but also ecological (Steele et al., 1992; Steele and Araman, 1996; Orlowski, 2003a, 2010; Orlowski et al., 2007). Environmental restrictions and increasing log costs have caused many sawmills to look at new ways to extract more value from their raw material. A more traditional way to accomplish this aim is to increase volume recovery. Firstly, a saw kerf can be reduced through improvements in saw design that reduce either the saw blade thickness or the side set of the saw (Manes and Lin, 1995; Wasielewski et al., 2007). However, it has been shown that changes in these two saw design factors can lead to increased within-board sawing variation, or deviation through the cut (Steele et al., 1992; Manes and Lin, 1995). These phenomena may be caused by decreasing either the saw blade specific stiffness or the saw blade operating stiffness due to the loss of saw blade stability (Stakhiev, 2000; Orlowski, 2003a, 2003b, 2010). The latter may also be the effect of the temperature increase caused by the passage of chips between the saw blade and kerf walls (Wasielewski, 2009).

Twin shaft multi-rip saws provide very efficient sawing of wood even in the case of large cutting depths. With regard to this advantage, these circular sawing machines are willingly and often used in sawmills of large productivity. Collar clamped circular saw blades of the "Multix" type (Figure 1a) are frequently applied on these machine tools. They are designed for ripping of hard and soft green wood. Except for traditional carbide teeth on the rim, the saw is additionally equipped with four scraper carbide edges (cleaning knives). Manufacturers of these tools advertise that the "Multix" circular saws provide fast removal of shavings from the cutting space. Nevertheless, some cases have been recorded of catastrophic damages of saw blades due to the passage of chips between the saw blade and kerf walls (Wasielewski, 2009). For this reason, a new circular saw design has been developed (Figure 1b). The new circular saw has larger static and dynamic stiffness, and thus protects a saw blade against deviations in the cut. Furthermore, special scrapers, placed just below each tooth, prevent the saw blade from heating by the uncontrolled chip flow on both sides of the saw blade (Wasielewski et al. 2007, 2008).

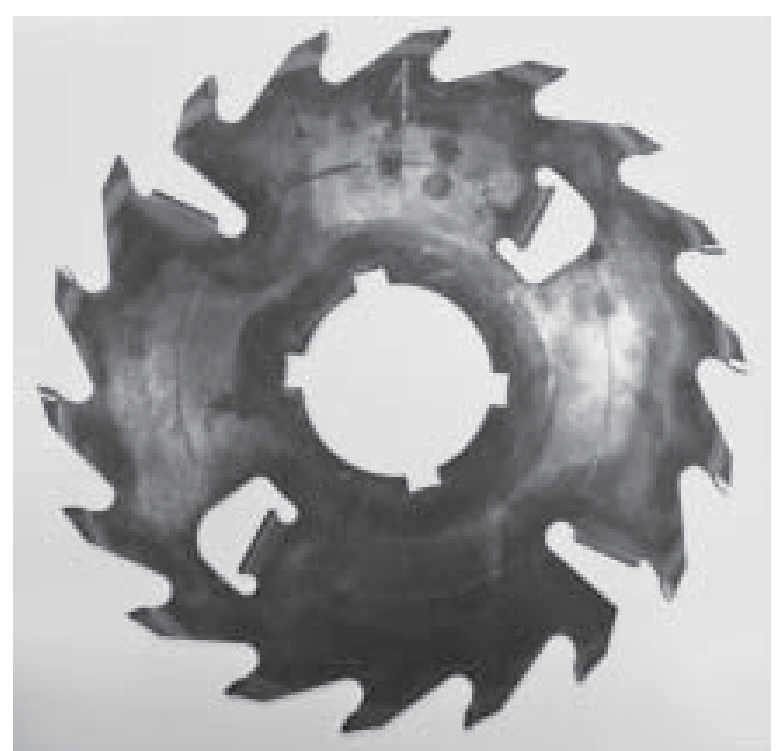

a)

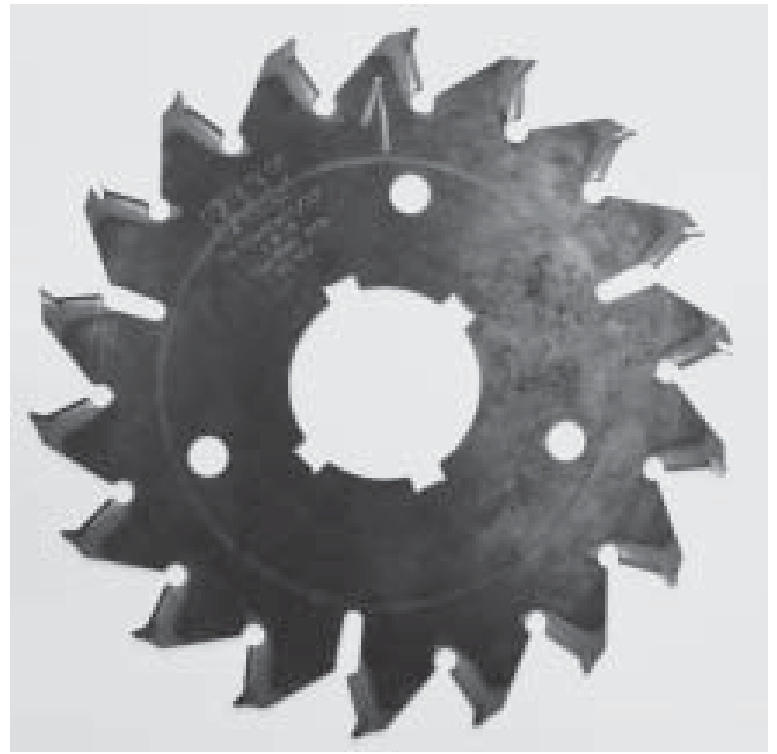

b)

Figure 1 Circular saw blades for rip sawing of (a) a traditional type "Multix" and (b) a new design "Ekomultiks" Slika 1. Listovi kružne pile za uzdužno piljenje a) tradicionalni tip "Multix" b) novodizajnirani list "Ekomultiks"

Each sawmill decides where its strong points are and how best to choose the most economical way to improve its own productivity. While one sawmill may prefer to improve its efficiency, another might concentrate its efforts on better utilization of raw materials. Operational reliability, however, is by far the most important factor (Sandvik, 1999). At the preliminary assessment stage, the effect of the kerf size upon raw material savings may be done by calculation of relative kerf losses $Q_{m}$, which are estimated in the case of sawing machines, for a gang of saws, as a ratio of the 


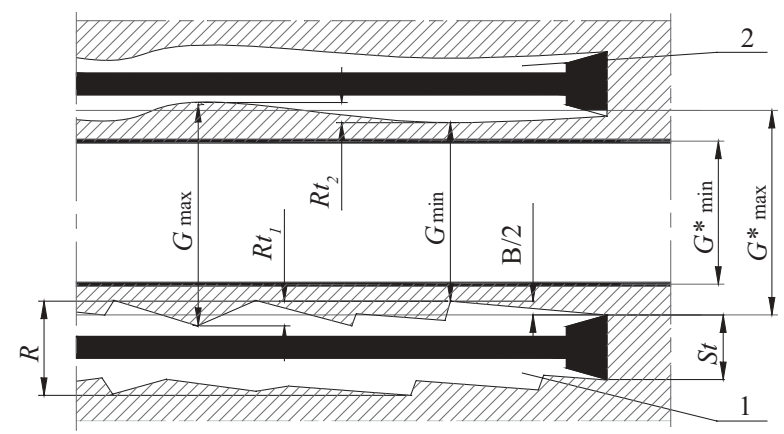

Figure 2 Kerf and board thickness changes, where $G^{*}{ }_{m}$ and $G^{*}$ are acceptable board thickness values, $G_{\text {min }}, G_{\max }$ are minimum and maximum values of the actual thickness Slika 2. Promjene širine propiljka i debljine piljenica, pri čemu su $G^{*}{ }_{\min }$ and $G^{*}{ }_{\max }$ prihvatljive vrijednosti debljine piljenica, a $G_{\min }, G_{\max }$ stvarne vrijednosti minimalne i maksimalne debljine piljenica

total loss volume and the stock volume (Orlowski 2003a, 2010; Wasielewski, 2010), provided that each board has the same thickness:

$$
Q_{m}=\frac{(n+1) R+\sum_{j=1}^{j=2} G_{b j}}{(n+1) R+\sum_{j=1}^{j=2} G_{b j}+n \cdot G_{\min }}
$$

where: $n$-number of produced boards, $R$ - maximum value of the real kerf calculated as $R=S_{t}+B$, and
$S_{\mathrm{t}}$ is a sum of theoretical kerf (overall set), $B$ is an axial run out in relation to the workpiece (equal to roughness of sawn surface $R_{\mathrm{t}}$, Figure 2), $G_{\min }$ is the minimal board thickness, and $G_{\mathrm{bj}}$ is the thickness of side boards (slabs or offcuts). If in the sawn pattern, elements have different thickness instead of $n \cdot G_{\min }, \sum_{j=1}^{j=n} G_{\min j}$ ought to be put into Eq. (1). Figure 2 shows two cases of real kerfs observed on board surface, the kerf \#1 when changes of the sawn profile could depend on circular saw blade rotational frequency, and the kerf \#2 when changes of the circular saw blade position are slow (observed snaking or wandering of the circular saw blade in the workpiece).

In some sawmills, determination of raw material yield is used more frequently. This concept illustrates which part of the raw material is utilized as ready-made product. The raw material yield $W_{\mathrm{m}}$ for the analyzed sawing pattern can be determined as follows:

$$
W_{\mathrm{m}}=1-Q_{\mathrm{m}}=\frac{n \cdot G_{\min }}{(n+1) \cdot R+\sum_{j=1}^{j=2} G_{b j}+n \cdot G_{\min }}
$$

In case of raw material with the same width $G$ and height $H$, on its whole length $L$, the assessment task seems to be very easy. However, in industrial reality, ready-made elements are often obtained from raw material of whose width and height change along its length (Figure 3). a)
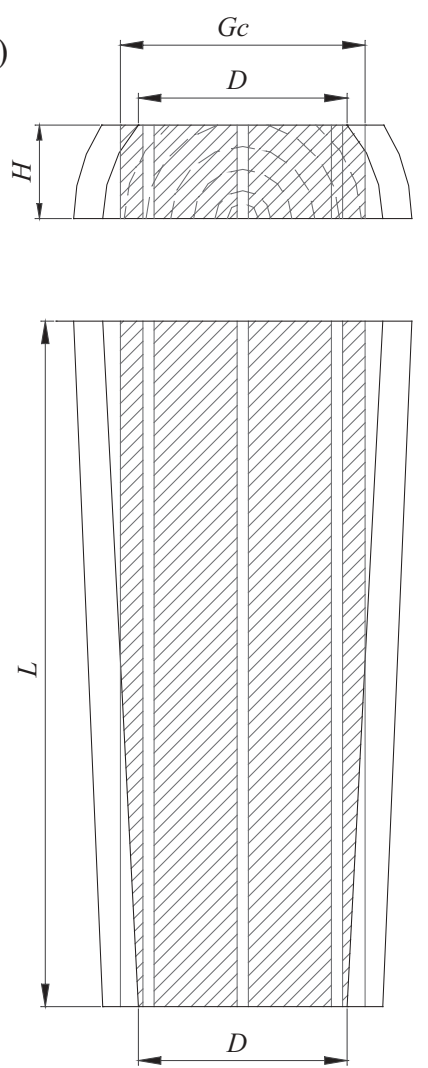

percentage distribution of dimension $D$

b)

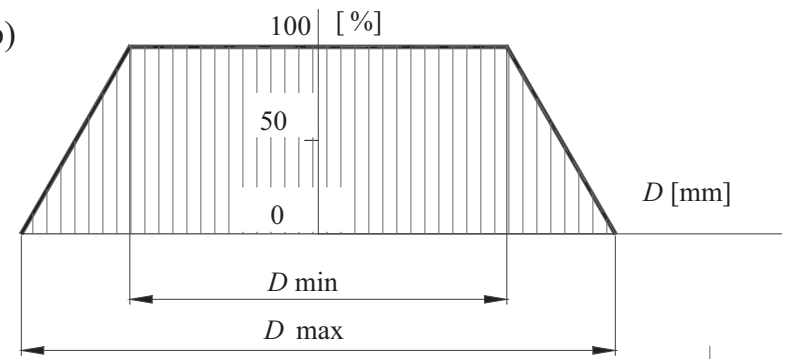

c)

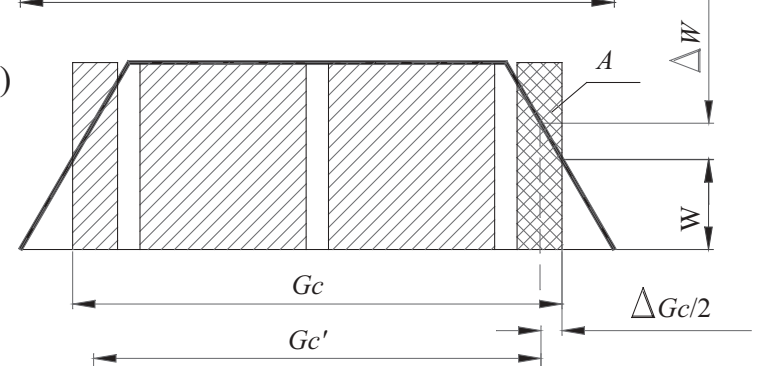

d)

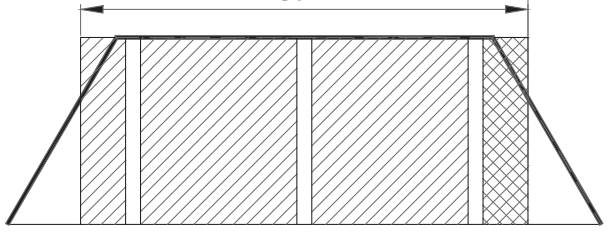

Figure 3 (a) Changes of width and height of side offcuts along the plank length, (b) percentage change distribution of the smallest width $D$, (c) determination of material yield for the defined total width of the circular saw blade span $G_{\mathrm{c}}$ and (d) the effect of the total width reduction on the material yield

Slika 3. a) Promjene širine i visine bočnih okrajaka uzduž piljenice; b) raspodjela postotne promjene najmanje širine D; c) određivanje iskorištenja sirovine za definiranu ukupnu širinu rasporeda listova kružnih pila $G ;$ d) učinak smanjenja ukupne širine na iskorištenje materijala 
The dimension $D$ is the smallest width of the individual plank with the height $H$ on both sides (Figure 3a). However, in the batch of the raw material that comes to the rip saw, the smallest dimensions $D$ can change in the range of $\left\langle D_{\min }, D_{\max }>\right.$. It can be assumed that during cutting of a quite large batch, the probability of rip sawing of planks with size $D$ in the range of $<D_{\text {min }}, D_{\text {max }}>$ has a linear distribution (Figure $3 \mathrm{~b}$ ). Thus, in case of the specific plank batch, when boards with the total width of the circular saw blade span $G c$ should be obtained, only $W \%$ of elements $A$ can achieve height $H$ along the whole plank length $L$. The use of the sawing technology, in which the total width of the circular saw blade span is reduced to the dimension $G c^{\prime}$, the quantity of elements $A$ with dimension $H$ along the whole plank length $L$ will increase in value of $\Delta W \%$ (Figure 3d). That increase of element $A$ efficiency is the increment of raw material yield $\Delta W$ and for the range of changes of the total width of the circular saw blade $\operatorname{span} D_{\text {min }}<G c<D_{\text {max }}$ it can be determined as:

$$
\Delta W=\frac{\Delta G \mathrm{c}}{D_{\max }-D_{\min }} \cdot 100=\frac{G \mathrm{c}-G \mathrm{c}^{\prime}}{D_{\max }-D_{\min }} \cdot 100, \%
$$

Hence, it can be noticed that during rip sawing operations of the plank in the shape as shown in Figure 3 the increment of raw material yield $\Delta W$ depends on both the necessary total width of the circular saw blade span $G_{c}$ of sawn boards and on the spread of the dimension range $D$ in the whole batch. In consequence, a reduction of material losses of the sawing process with circular saw blades demands for a reduction of the tooth overall set of the circular saw (application of thinner saw blades), an increase of sawing accuracy (reduction of circular saw blades axial run-out) and a reduction of the saw blade spacing. An evident proof of the application of a new design of circular saws is especially perceptible if lamellae are an effect of ripsawing (Wasielewski and Orlowski, 2010). In this case the raw material yield $W_{m}$ increased by about $10 \%$, and there were about $16 \%$ less chips. Hence, there was more wood from side boards, which could be raw material for the production of chips for paper mills for instance. What is more, a reduction of power consumption could be expected by roughly $16 \%$. Since cutting power is a function of the specific cutting resistance $k_{c}$, cutting speed $v_{\mathrm{c}}$ and a total area of cut (Manžos 1974):

$$
A_{D T O t}=z_{\mathrm{c}} \cdot h \cdot S_{\mathrm{t}}
$$

where: $z_{\mathrm{c}}$ is an average number of teeth being in the contact with the kerf, $h$ is an average uncut chip thickness and $S_{t}$ is a kerf (the width of cut), which is reduced.

The goal of this paper is to make the comparative assessment of both the traditional collar clamped circular saw blades of the "Multix" type and the new design of the circular saw "Ekomultiks" in industrial (plant) conditions.

\section{MATERIAL AND METHODS}

\section{MATERIJALI I METODE}

Circular saw blades of the new design ("Ekomultiks", Figure 1b) and the traditional issue ("Multix"

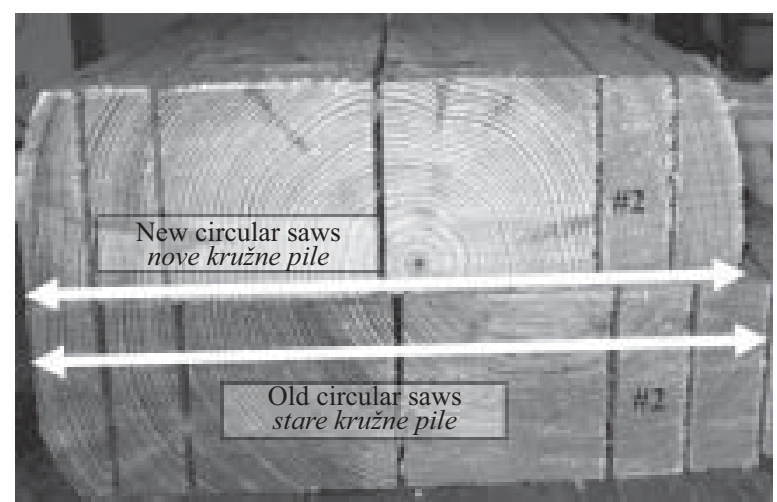

Figure 4 Comparison of pine planks slotted with gangs of circular saws in case of sawing with traditional circular saws "Multix" (lower plank) and new circular saws "Ekomultiks" (upper plank); where: \#2 are control boards Slika 4. Usporedba borove prizme prorezane slogom kružnih pila pri piljenju tradicionalnom pilom "Multix" (niža piljenica) i novom kružnom pilom "Ekomultiks" (gornja piljenica); kontrolna piljenica označena je sa \#2

type, Figure 1a), both types with carbide tipped teeth, have been examined in industrial (plant) conditions on the twin shaft multi-rip saw Heavy Duty PRW422 (f. TOS Svitavy, CZ). The experiment design variants corresponded to circular saw blade specifications as follows:

1. Variant 1, the traditional issue "Multix": diameter $\varnothing 300 \mathrm{~mm}$, overall set (kerf) $S_{\mathrm{t}}=3.7 \mathrm{~mm}$, saw blade thickness $s=2.5 \mathrm{~mm}$ separated with distance pieces of $\varnothing 110 \mathrm{~mm}$ (nominal control board thickness $25.3 \mathrm{~mm}$ );

2. Variant 2, the new design "Ekomultiks": diameter $\varnothing 300 \mathrm{~mm}$, overall set (kerf) $S_{\mathrm{t}}=3.4 \mathrm{~mm}$, saw blade thickness $s=2.5 \mathrm{~mm}$ separated with distance pieces of $\varnothing 110 \mathrm{~mm}$ (nominal thickness of $25.6 \mathrm{~mm}$ for control boards);

3. Variant 3, the new design "Ekomultiks": diameter $\varnothing 300 \mathrm{~mm}$, overall set (kerf) $S_{\mathrm{t}}=3.1 \mathrm{~mm}$, saw blade thickness $s=2.2 \mathrm{~mm}$ separated with distance pieces of $\varnothing 130 \mathrm{~mm}$ (nominal thickness of $25.1 \mathrm{~mm}$ for control boards).

Pine planks (Pinus sylvestris L.) were sawn of the height $H=105 \mathrm{~mm}$, and moisture content $\mathrm{MC}$ of 25-32 $\%$ (Figure 4). During one 8-hour shift, sawn lumber at the controlled position in the gang (boards \#2, nominal thickness in the range of 25.1-25.6 $\mathrm{mm}$ according to the experiment design variants, Figure 4), was measured with the digital caliper (f. Gedore). Measurements were carried out on the upper $(\mathrm{Gg})$ and lower measurement line $(\mathrm{Gd})$, respectively. Both measurement lines were positioned about $10 \mathrm{~mm}$ from the board edge, and at each line three measurements of thickness were done (at points $100 \mathrm{~mm}$ away from the board ends and additionally one in the middle of the board).

\section{RESULTS AND DISCUSSION}

\section{REZULTATI I RASPRAVA}

Comparison of two pine planks slotted during industrial experiments with gangs of circular saw blades in 
case of sawing with traditional circular saws "Multix" (the lower plank) and new circular saws "Ekomultiks" (the upper plank) is presented in Figure 4. In this picture the position of the measured board is shown as \#2.

The measurement results of board thickness determined on the lower and upper measurement line for ripsawing with "Multix" circular saw blades and "Ekomultiks" circular saw blades are presented in Figure 5. While the "Multix" circular saw blades were used, the range of lumber thickness distribution was $0.5 \mathrm{~mm}$. In the next step "Multix" circular saw blades were replaced with "Ekomultiks" circular saw blades (saw blade thickness of $2.5 \mathrm{~mm}$ ) and separated with old distance pieces in the gang. In such changed conditions, the lumber thickness distribution of $0.3 \mathrm{~mm}$ was obtained both on the upper and lower line. Eventually, we have decided to reduce both circular saw blade thickness $(s=2.2 \mathrm{~mm})$ and distance pieces thickness, and the effects of sawing with "Ekomultiks" circular saw blades separated with new distance pieces, with an outside diameter enlarged to $\varnothing 130 \mathrm{~mm}$, are presented in Figure $5 \mathrm{c}$. In this case, the lumber thickness distribution was $0.3 \mathrm{~mm}$ both on the upper and lower line. However, it should be emphasized that a reduction of saw blade thickness and a simultaneous increase of the distance piece diameter (from $\varnothing 110 \mathrm{~mm}$ to $\varnothing 130 \mathrm{~mm}$ ) has guaranteed the same value of the circular saw blade stiffness.

Additionally, comparison of effects of materialsaving technology and the traditional sawing technology may be done analytically on the basis of distribution of the input workpiece width changes in percents $D$ (Figure 6). In the examined sawing conditions, from 100 sawn pine planks the following pieces have been

a)

b)

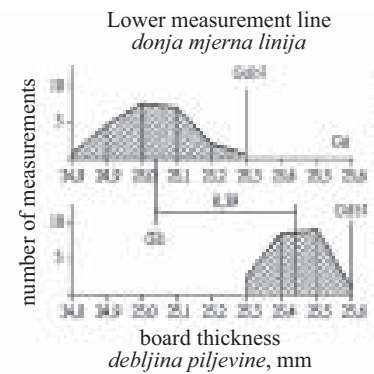

c)

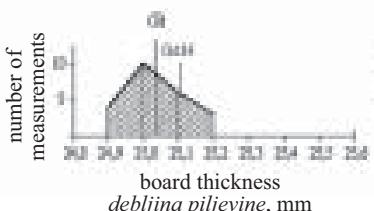

Figure 5 Board thickness determined on the lower and upper measurement line for (a) sawing with "Multix" circular saw blades $\left(S_{\mathrm{t}}=3.7 \mathrm{~mm}\right)$, (b) "Ekomultiks" circular saw blades $\left(S_{\mathrm{t}}=3.4 \mathrm{~mm}\right)$ with the use of old distance pieces and (c) "Ekomultiks" circular saw blades $\left(S_{\mathrm{t}}=3.1 \mathrm{~mm}\right)$ with the use of a new type of distance pieces, where: $G_{\mathrm{dN}}, G_{\mathrm{gN}}-$ board nominal thickness, $G_{\mathrm{d}}, G_{\mathrm{g}}$ - board average thickness Slika 5. a) Debljina piljenice određena na donjoj i gornjoj liniji mjerenja pri piljenju kružnom pilom "Multix" $\left(S_{t}=3,7\right.$ $\mathrm{mm}), \mathrm{b})$ kružnom pilom "Ekomultiks" $\left(S_{\mathrm{t}}=3,4 \mathrm{~mm}\right), \mathrm{uz}$ uporabu starih distantnih prstenova; c) kružnom pilom "Ekomultiks" ( $\left.S_{\mathrm{t}}=3,1 \mathrm{~mm}\right)$, uz uporabu novog tipa distantnih prstenova, pri čemu su $G_{\mathrm{dN}}, G_{\mathrm{gN}}$ - nominalne debljine piljenica, $G_{\mathrm{d}}, G_{\mathrm{g}}-$ srednje debljine piljenica

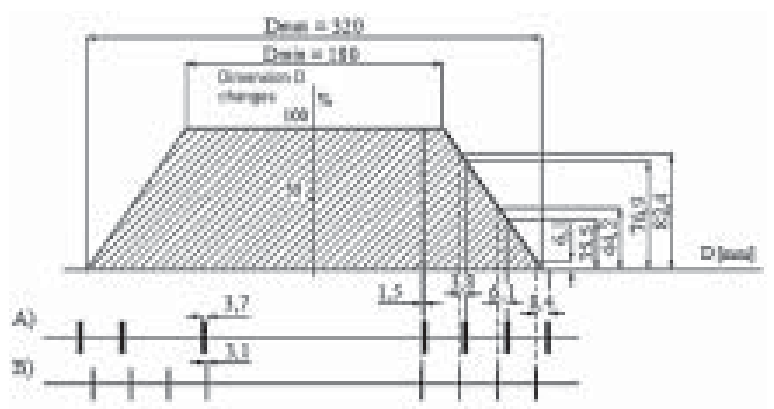

Figure 6 Distribution of changes of the input workpiece width and circular saw blade spacing for sawing with "Multix" circular saw blades (A), and "Ekomultiks" circular saw blades (B)

Slika 6. Raspodjela promjena ulaznih širina obradaka $\mathrm{i}$ razmaka između listova pila pri piljenju (A) kružnom pilom "Multix" i (B) kružnom pilom "Ekomultiks"

obtained: $2 \times(76.9 \mathrm{pcs}+35.5 \mathrm{pcs})=224.8$ pieces of side lumber in the case $A$, and in the case B $2 \times(82.4$ pcs $+44.2 \mathrm{pcs}+6.1 \mathrm{pcs})=265.4$ items of the side lumber. Thanks to the application of the pro-ecological technology, the following results have also been achieved: an increase of about $18 \%$ in the amount of side lumber, roughly $16 \%$ less sawdust (as an effect of kerf reduction) and about $16 \%$ lower values of the cutting power consumption (see explanation in Chapter 1).

\section{CONCLUSION \\ 4. ZAKLJUČAK}

On the basis of the conducted experiments and analyses, it can be stated that the use of narrow-kerf saw blades and an increase of the sawing accuracy reduces both the cutting losses and cutting energy consumption in wood sawing. The better use of the input raw material in the presence of the lower cutting energy consumption is the basis of the pro-ecological technologies of wood sawing. The application of such a technology allows the reduction of raw material consumption and furthermore brings measurable economical profits.

However, the actual profits arising out of raw material and energy savings in the case of application of the new sawing technologies (unconventional ones) depends on specific sawmill conditions, i.e.: the sawing pattern, the state of the rip sawing machine and its maintenance, and the staff attitude, as a really important issue. Eventually, the realization of economical wood sawing with circular saw blades seems not to be viable until the whole system of sawing fulfils the defined requirements.

\section{Acknowledgements Zahvala}

The authors from the GUT would like to thank the firm GASSTECH PPH Sp. z o. o. (Suwalki, PL) for the donation of the circular saw blades used in the tests. Furthermore, we also have to thank the firm P.U.P "COMPLEX" Sp. z o.o (PLC, PL) which has allowed us to conduct experiments at its production sawmills in Dziemiany and Trzebun. The authors would like to acknow- 
ledge that the circular saw blade "Ekomultiks" was awarded with the Gold Medal at the International Trade Fair of Machines and Tools for the Wood and Furniture Industries "Drema 2010" in Poznan (Poland) and with the Silver Prize at the Seoul International Invention Fair SIIF 2011 in Seoul (Korea). Some parts of the paper have been presented during the $20^{\text {th }}$ International Wood Machining Seminar in Skellefteå in Sweden.

\section{REFERENCES}

\section{LITERATURA}

1. Maness, T. C.; Lin, Y., 1995: The Influence of Sawkerf and Target Size Reductions on Sawmill Revenue and Volume Recovery. Forest Prod. J., 45(11/12): 43-50.

2. Manžos, F. M., 1974: Derevorežuŝie Stanki. (In Russian: Wood cutting machine tools). Izdatel'stvo "Lesnaâ promyšlennost", Moskva.

3. Orlowski, K., 2003a: Materiałooszczędne i dokładne przecinanie drewna piłami. (In Polish: Narrow-kerf and accurate sawing of wood). Seria Monografie nr 40, Wydawnictwo Politechniki Gdańskiej, Gdańsk.

4. Orlowski, K., 2003b: Some approaches to the determination of saw blade stiffness. Drvna Industrija 54(4):207215.

5. Orlowski, K. A., 2010: The fundamentals of narrow-kerf sawing: the mechanics and quality of cutting. (Dzurenda L. and Banski A., eds.), Technical University in Zvolen, Faculty of Wood Sciences and Technology, Zvolen, Technical University in Zvolen.

6. Orlowski, K.; Wasielewski, R.; Szyszkowski, S.; Wnukowski, E., 2007: The effect of improved cutting conditions of the circular saw blade on precision of cutting. Ann. WULS-SGGW, For and Wood Technol. No 62:100-104.

7. Stakhiev, Y. M., 2000: Today and Tommorow Circular Sawblades: Russian Version. Holz als Roh- und Werkstoff, 58:229-240, http://dx.doi.org/10.1007/s001070050417.

8. Sandvik, 1999: Production, use and maintenance of wood bandsaw blades. A manual from Sandvik Steel. AB Sandvik Steel, Sandviken, Sweden, May, S-336-ENG.
9. Steele, P. H.; Wade, M. W.; Bullard, S. H.; Araman, P. A., 1992: Relative kerf and sawing variation values for some hardwood sawing machines. Forest Prod. J., 42 (2):3339.

10. Steele, P. H.; Araman, P. A., 1996: Analyzing investments in thin-kerf saws. In: Hardwood Symposium Proceedings. May 8-11, pp. 55-60.

11. Wasielewski, R.; Orlowski, K.; Szyszkowski, S.; Wnukowski, E., 2007: Zgłoszenie Patentowe (Patent pending) P.382274, Piła tarczowa z rowkami wiórowymi. (In Polish: Circular saw blades with chip spaces) (2007.04.24).

12. Wasielewski, R., 2009: Influence of chip transport method on effects of cutting with circular saw. In: Górski, J., Zbieć, M. (Eds.) Wood machining and processing - product quality and waste characteristics. WULSSGGW, Warsaw. pp. 44-59.

13. Wasielewski, R., 2010: Losses and raw material yield of wood sawing processes. Ann. WULS-SGGW, For and Wood Technol. 72. No 72: 414-417.

14. Wasielewski, R.; Orlowski, K., 2010: Pro-ecological technology of wood sawing with circular saw blades. Ann. WULS-SGGW, For and Wood Technol. 72: 423-426.

15. Wasielewski, R.; Orlowski, K.; Szyszkowski, S.; Wnukowski, E., 2008: Piły tarczowe o podwyższonej sztywności. (In Polish: Circular saw blades with stiffness increased) In: Stós, J. (Ed.) Obróbka skrawaniem - Innowacje, Szkoła Obróbki Skrawaniem ; 2. Kraków : IOS Instytut Zaawansowanych Technologii Wytwarzania, pp. 426-433.

\section{Corresponding author:}

Prof. KAZIMIERZ A. ORLOWSKI, Ph.D.

Gdansk University of Technology

Faculty of Mechanical Engineering

Department of Manufacturing Engineering and Automation

Narutowicza 11/12, 80-233 Gdansk, POLAND association with IVALSA/CNR Trees and Timber Institute, ITALY

e-mail: korlowsk@pg.gda.pl 